\title{
SADDLE PLANTING SYSTEM, ANEW WHEAT SOWING METHOD IN SOUTHEASTERN ANTOLIA ENVIRONMENT CONDITION
}

\author{
Enver KENDAL ${ }^{1} \quad$ Sertaç TEKDAL1 \\ 1 GAP International Agricultural Research And Training Center,Diyarbakır /TURKEY
}

\begin{abstract}
Especially in aqueous conditions, where the ground water level is high or when grain crops alternation with cotton plant, saddle planting system is useful because this system reduce costs in Southeastern Anatolia Region near Syria and Iraq. This planting system is going common in farm condition in our region. Total of 8 durum wheat varieties were compared by using traditional planting and saddle planting methods in Diyarbakir ecological conditions in 2010-2011 production season. Acording to the combined analysis, significant differences were determined at the level of $1 \%$ and $5 \%$, in terms of sowing methods, genotype and genotype $\mathrm{x}$ planting methods interactions in terms of grain yield, test weight and thousand of grain weight. The combined analysis on the data of different planting method; genotype, planting method and genotype x planting method interactions were significant at the level of 1 to $5 \%$. According to analysis on planting methods, grain yield changed between $7430-7950 \mathrm{~kg} / \mathrm{ha}-1$, test weight between $80.9-81.1 \mathrm{~g}$ and thousand of grain weight between 44.7-47.1 g. According to results; grain yield and hektoliter weight were high in conventional method of planting. Saddle planting system, in irrigation, weed struggle, disease, pest management, harvesting operations can be made more comfortable. Acording to result of this study, depending on the conditions (alternation planting cotton, irrigated areas, or the price of seed is high ) suggest that saddle planting system can be applied successfully in wheat cultivation.
\end{abstract}

\section{INTRODUCTION}

Wheat is important cereal crop and serves a staple food in many countries of the world and it has widest distribution among cereal crops in Turkey. Durum wheat is a traditionally important crop in Southeastern Anatolia Region of Turkey near Syria, Iraq and Iran. Its importance still continues due to production and export potent. Therefore, the studies focus on both the breeding and cultivation techniques in GAP International Agricultural Research and Training Center/Diyarbakir. In the studies, until now a very efficient and high quality durum wheat varieties were developed to suitable conditions in region. However, the studies focuses on training packages to obtatin high yield from these varieties, it would be useful more. therefore, the method of saddle planting has been developed to provide save irrigation water and amount of seed, facilitate cultural operations and after harvesting of cotton cultivation, could make planting late period. 
Wheat is planted through broadcasting on a large area after cotton is harvested in South-Eastern Anatolian. Broadcasting do not only requires higher seed rate but also results in untidy plant population. On the other hand, drill sowing method is recommended because of its uniform seed distribution and planting at desired depth, which usually results in higher germination and uniform stand (Kiliç and Gürsoy, 2010). Seeding rate is one of the important production factors. Higher wheat grain yield with better quality requires appropriate seeding rate for different cultivars. Increase in seed rate above optimum level may only enhance production cost without any increase in grain yield (Rafique et al., 2010). The optimum seed rates for wheat by altering with variety, location and method of planting. Larson and Watson (2010) reported that more and more producers are growing wheat and other small grains in no-tillage cropping systems because no-till systems produce major ecological and economic benefits. If growers can achieve adequate stands in no- till systems, grain yields usually are similar to conventional wheat systems. Ridge planting method, primarily provides saving irrigation water and seed. Besides, due to regulation of traffic on the field, it is ease to selection foreign kind in seed production and increase efficiency and reduce soil erosion, seems to be preferred as a system. Especially in the GAP region, opened new areas for irrigation, can be considered as an application in terms of efficient use of water. With normal sowing seed drill to be modified, it's adaptation can be achieved without creating an additional cost to the farmer (K1lıç, 2005).

\section{MATERIALS AND METHODS}

The experiments were conducted in 2010 - 2011 in GAP International Agricultural Research and Training Center in Diyarbakir of Turkey (Latitude: $37^{\circ}$ 56'36"N, longitude: $043^{\circ} 15^{\prime} .13^{\prime \prime} \mathrm{E}$ at an elevation of $602 \mathrm{~m}$ above sea level). The soil of the experimental area is siltyl loam and slightly alkaline (7.83) in reaction, low in organic matter $(1.45 \%)$, medium in available $\mathrm{P}(4.3 \mathrm{~kg} / \mathrm{da}-1)$ and high in $\mathrm{K}(95 \mathrm{~kg} / \mathrm{da}-1)$. The weather conditions during the crop cycles are presented in Table 2. There was higer rainfall and lower average temperatures after planting in 2010 - 2011 as compared to long term. Irrigation is important during production season in saddle of sowing method just for one, but the precipitation was high. So, the experiment didn't irrigate in planting of saddle method. Experiment was conducted as a randomized complete block design with three replications using a split plot treatment arrangement. The cultivars were randomized in the main plots and seed rate in the sub-plots. The net plot size was $2.8 \times 5 \mathrm{~m}$. The seeding rates were used 300 seeds $\mathrm{m}-2$. Acording to research (Kıliç (2005), seeding rates are available 250 seed $\mathrm{m}-2$ in seddle planting method and 400 seed m-2 in traditional planting method Southeastern Anatolia Region environment condition. So, seed rate was used middle of these two systems. The trial was sowed in 25 October. The cultivars were used Altıntoprak, Artuklu, Eyyubi, Fırat 93, Güneyyıldızı, Sarıçanak, Şahinbey and Zühre which are widely grown in South-Eastern Anatolian region (Table 1). Wheat was grown in rotation 
following cotton. Cotton as a summer crop was planted in May and harvested in October. Wheat as a winter crop was planted in the optimum period of late November to early December and harvested in late June and early July. New raised beds were prepared for cotton and after harvesting of cotton, wheat was grown in winter season under zero tillage following a required repairing of the beds (Figures 1 and 2). Planting was carried out with a planter modified for planting two rows of seed on the top of permanent bed. The width of the ridge was $70 \mathrm{~cm}$ from furrow bottom to furrow bottom. The space between each row on ridge was $15 \mathrm{~cm}$.

Table(1): The name and origin and time of registered of wheat varietes used inexperiment

\begin{tabular}{|c|l|c|}
\hline Name of Cultivar & Origin & Time of registered \\
\hline Altıntoprak & GAPUTAEM & 1998 \\
\hline Artuklu & GAPUTAEM & 2008 \\
\hline Eyyubi & GAPUTAEM & 2008 \\
\hline Firat 93 & GAPUTAEM & 1993 \\
\hline Güneyyıldız1 & GAPUTAEM & 2010 \\
\hline Sarıçanak & GAPUTAEM & 1998 \\
\hline Şahinbey & GAPUTAEM & 2008 \\
\hline Zühre & GAPUTAEM & 2010 \\
\hline
\end{tabular}

GAPUTAEM :GAP International Agricultural Research and Training Center

Table (2):The annual and long term precipitation and temperature values belong the study time and place

\begin{tabular}{|c|c|c|c|c|}
\hline \multirow{2}{*}{ Months } & \multicolumn{2}{|c|}{ Temperatures (oC) } & \multicolumn{2}{c|}{ Precipitation (mm) } \\
\cline { 2 - 5 } & $2010-2011$ & Long term & $2010-2011$ & Long term \\
\hline September & 27.0 & 24.9 & 0.4 & 3.4 \\
\hline October & 18.1 & 17.2 & 63.0 & 30.4 \\
\hline Novomber & 11.1 & 10.0 & 0 & 55.9 \\
\hline December & 6.5 & 4.2 & 48.0 & 71.5 \\
\hline January & 3.5 & 1.8 & 40.0 & 80.2 \\
\hline February & 4.7 & 3.6 & 49.9 & 68.6 \\
\hline March & 9.0 & 8.1 & 46.6 & 62.2 \\
\hline April & 13.0 & 13.8 & 209.0 & 72.1 \\
\hline May & 17.7 & 19.3 & 21.6 & 42.9 \\
\hline June & 25.5 & 25.9 & 13.6 & 7.1 \\
\hline Total & & & 550.8 & 494.3 \\
\hline
\end{tabular}

htpp// www.meteor.gov.tr

The whole dose of $\mathrm{P}$ (60 kg P ha-1) with half dose of nitrogen (60 kg N ha-1) were applied at sowing time and the remaining nitrogen (60 $\mathrm{kg} \mathrm{N}$ ha-1) was used at the begining of stem elongation time. All other agronomic practices like irrigation, weeding etc. were kept normal and uniform for all the treatments. 
Data on growth and yield components were collected using standard procedures and were analyzed statistically by using Fisher's analysis of variance technique. Least significance difference (LSD) tests were performed to determine the significant differences between individual means. All statistical analyses were performed using the SAS program (SAS Institute, 1999).

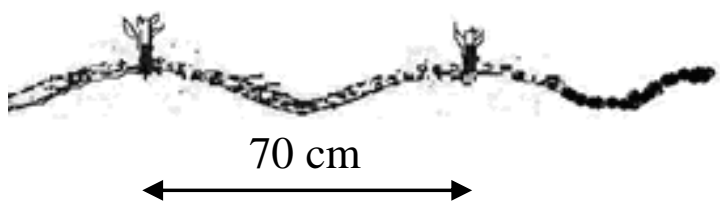

Figure 1. Stalks cut after harvest of cotton.

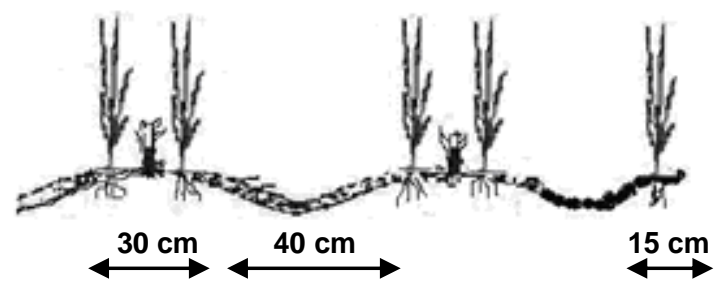

Figure 2. The Saddle Planting method, wheat planted after cotton on permanent saddle. 


\section{RESULTS AND DISCUSSION}

Acording to the combined analysis on the data of different planting methods; genotype, planting method and genotype $\mathrm{x}$ planting method interactions had significant at the level of 1 to $5 \%$.

Test Weight: Planting Method was significant in level 5\%, variates and varietes $\mathrm{x}$ planting method interactions was significant in level 1\% (Table 3). Data regarding test weight showed that maximum test weight $(81.1 \mathrm{~kg} / \mathrm{hl})$ was obtained from method of conventional planting followed by method of saddle planting $(80.9 \mathrm{~kg}$ hl). Due to it was thought low the number of spikes per plant and kernels per spike in planting method of conventional, the results of test weight was high in method of conventional than method of saddle planting. The test weight of wheat varieties ranged from 79.5 to $82.3 \mathrm{~kg}$ hl. The maximum test weight obtained from Şahinbey cultivar, the minimum test weight was obtained from Saricanak cultivar. Şahinbey is new than Saricanak (Table 1). When these new cultivars was registered, the breeders especially concentrated on teknologicial qualty criteria (test weight and tousand grain yield). So, these new cultivars have high test weight. Varietes $\mathrm{x}$ planting method interactions had significant effect on test weight. Maximum test weight $(83.1 \mathrm{~kg} \mathrm{hl})$ was obtained from method of conventional planting in Şahinbey, minimum test weight $(79.3 \mathrm{~kg} \mathrm{hl})$ was obtained planting saddle method in Sarıçanak cultivar. Acording to Atlı at al (1999) and Sade at al (1999), test weight is change under differet planting methods, varietes, ecological conditions, cultural practices, pest and disease. Kendal at al (2011), studied on ten durum varietes in same region to determine test weight, the results were changed between 77.3-81.7 $\mathrm{kg} / \mathrm{hl}$. The results obtained of this study showed that results of two studies changed between same values.

Table (3):Means of HLW and TGW of durum wheat varieties under Conventional cultivation and Saddle cultivation

\begin{tabular}{|c|c|c|c|c|c|c|}
\hline \multirow[t]{3}{*}{ Cultivar } & \multicolumn{3}{|c|}{ Hectoliter weight (kg/hl-1) } & \multicolumn{3}{|c|}{ Thousand grain weight (g-1) } \\
\hline & \multicolumn{3}{|c|}{ Planting of conventional } & \multicolumn{3}{|c|}{ Planting of saddle System } \\
\hline & $\mathrm{SC}$ & SS & Mean & $\mathrm{SC}$ & SS & Mean \\
\hline Altıntoprak & $80.5 \mathrm{fg}$ & $79.9 \mathrm{~h}$ & $80.2 \mathrm{E}$ & 44.3 & 47.7 & $46.0 \mathrm{C}$ \\
\hline Artuklu & $81.2 \mathrm{e}$ & $81.2 \mathrm{e}$ & $81.2 \mathrm{C}$ & 44.5 & 49.0 & $46.7 \mathrm{C}$ \\
\hline Eyyubi & $81.9 \mathrm{c}$ & $80.5 \mathrm{fg}$ & $81.2 \mathrm{C}$ & 44.1 & 44.1 & $44.1 \mathrm{D}$ \\
\hline Firat 93 & $81.5 \mathrm{~d}$ & $80.3 \mathrm{~g}$ & $80.9 \mathrm{D}$ & 51.8 & 46.4 & $49.1 \mathrm{~B}$ \\
\hline Güneyy1ldız1 & $80.4 \mathrm{fg}$ & $81.4 \mathrm{de}$ & $80.9 \mathrm{D}$ & 41.7 & 43.0 & $42.4 \mathrm{E}$ \\
\hline Sarıçanak & 79.71 & $79.3 \mathrm{j}$ & $79.5 \mathrm{~F}$ & 42.5 & 43.6 & $43.1 \mathrm{DE}$ \\
\hline Şahinbey & $83.1 \mathrm{a}$ & $81.4 \mathrm{de}$ & $82.3 \mathrm{~A}$ & 49.7 & 54.0 & $51.8 \mathrm{~A}$ \\
\hline Zühre & $80.6 \mathrm{f}$ & $82.7 \mathrm{~b}$ & $81.6 \mathrm{~B}$ & 38.5 & 49.0 & $43.8 \mathrm{DE}$ \\
\hline Total & $81.1 \mathrm{~A}$ & $80.9 \mathrm{~B}$ & & $44.7 \mathrm{~B}$ & $47.1 \mathrm{~A}$ & \\
\hline $\mathrm{CV}(\%)$ & \multicolumn{3}{|c|}{0.16} & \multicolumn{3}{|c|}{3.03} \\
\hline LSD (0.05) & \multicolumn{3}{|c|}{$\begin{array}{l}\text { Method of planting : } 0.240524 * \\
\text { Varietes : } 0.159407 * * \\
\text { Varietes x m. of planting: } \\
0.223133 * *\end{array}$} & \multicolumn{3}{|c|}{$\begin{array}{l}\text { Method of planting: } 1.053552 * \\
\text { Varietes : } 1.650056^{* *} \\
\text { Varietes x m. of planting: } \\
2.333528 \mathrm{NS}\end{array}$} \\
\hline
\end{tabular}


$* *=$ means significiantly level of $1 \%, *=$ means significiantly level of $5 \%, \mathrm{NS}=$ not significiantly

Thousand grain weight: Method of sowing was significant in level 5\%, variates was significant in level $1 \%$, there was not significiant effect in varietes $\mathrm{x}$ planting method interactions (Table 3). Data regarding thousand grain weight showed that maximum value $(47.1 \mathrm{~g})$ was obtained from method of saddle sowing followed by method of conventional sowing ( $44.7 \mathrm{~g}$ ). Acording the result of thousand grain weight, values were high in method of saddle sowing than method of conventional without Firat cultivar. Planting method had a significant impact on the thousand grain weight of wheat. These results are in agreement with Khokhar et al. (1985), Hussain et al. (2001) and Kiliç et al. (2010). The thousand grain weight of wheat varieties ranged from 42.4 to $51.8 \mathrm{~g}$. The maximum thousand grain weight obtained from Şahinbey cultivar, the minimum test weight obtained from Güneyyıldızı cultivar. Şahinbey is the best on teknologicial between these varietes. When Şahinbey was registered, the breeders especially concentrated on teknolojicial qualty criteria (tousant grain yield). So, Şahinbey have high thousand grain weight.Varietes $\mathrm{x}$ planting method interactions had not significant effect on thousand grain weight. Maximum thausand grain weight $(54.0 \mathrm{~g})$ was obtained from saddle planting method in Şahinbey, minimum test weight $(41.7 \mathrm{~g})$ was obtained method of conventional planting in Güneyyıldızı cultivar. Method of saddle planting gived high TGW. Due to in the saddle planting method firstly, produced more healthy plants which in turn synthesized healthier and plump seed, secondly it may be due to more favorable environmental conditions. Acording to Aydin at al (1999), Kılıç at al (2010) and Kendal at al (2011) and 20), thousand grain weight is change under differet metod of planting, varietes, ecological conditions, cultural practices, pest and disease. Kendal at al (2011), studied on ten durum varietes in same region to determine thousant grain weight, the results were changed between $30.0-42.8 \mathrm{~g}$. The results were different between studies, because of the results are changing under year conditions and different planting methods. Grain yiled: Effect of planting method, variates and varietes $\mathrm{x}$ planting method interactions was significant on grain yield. (Table 4). Grain yield varied considerably during the experimental period. Data regarding wheat grain yield showed that maximum wheat grain yield $(7950 \mathrm{~kg} / \mathrm{ha}-1)$ was obtained from planting method of conventional followed by planting method of saddle $(7430 \mathrm{~kg}$ ha-1). Due to during the experimental period precipitation was high, the planting method of conventional gave high grain yield than planting method of saddle, but the results would changed between two method, If saddle planting method were irrigation and were not high precipitation during season. There were great differences between varieties in grain yield. The yield of wheat varieties ranged from 5764 to $9034 \mathrm{~kg}$ ha-1. The varieties, Şahinbey, Sariçanak and Zühre, were productive cultivars with high grain yield. The lowest yielding variety, Altintoprak is older than high productive cultivars. Varietes x planting method interactions had significant effect on grain yield. Overall maximum grain yield (9585 kg ha-1) was obtained from method of conventional planting in Şahinbey cultivar. Minimum grain yield (5699 kg ha-1) was obtained method of saddle planting in Altintoprak cultivar. Sayre and Moreno Ramos (1997) and Mollah et al. (2009) reported that seed rate did not have significant effect on 
grain yield of wheat in bed planting conditions. However, Sayre and Moreno (1997) reported that some farmers had been using seed rates as low as 50-75 kg ha-1, while Kabakçi (1999) suggested that $100 \mathrm{~kg}$ ha-1 seeding rate was appropriate for wheat on bed planting system. Kiliç and Gürsoy (2010), the grain yield for the optimum seeding rate was estimated at 253 seed per m-2 (approximately $111.4 \mathrm{~kg} \mathrm{~h}-1$ ) for wheat grown successfully on permanent bed in cotton wheat cropping system. As we have seen the results of this study also supports the results of our study. Kiliç and Gürsoy (2010), studied on two varietes to determine right seed $\mathrm{m}-2$ for sowing, the results were changed between $5367.6 \mathrm{~kg}$ ha-1 and $2746.1 \mathrm{~kg}$ ha- 1 . but the precipitation during study season was low in their study than our

Table (4): Mean of grain yield of durum wheat varieties under conventional cultivation and saddle cultivation

\begin{tabular}{|c|c|c|c|}
\hline \multirow{2}{*}{ Cultivar } & \multicolumn{3}{|c|}{ Grain yield (kg/ha) } \\
\cline { 2 - 4 } & $\begin{array}{c}\text { Planting of } \\
\text { Conventional }\end{array}$ & $\begin{array}{c}\text { Planting of saddle } \\
\text { System }\end{array}$ & Avarage \\
\hline Altıntoprak & $5830 \mathrm{~h}$ & $5699 \mathrm{~h}$ & $5764 \mathrm{E}$ \\
\hline Artuklu & $6421 \mathrm{fg}$ & $5935 \mathrm{gh}$ & $6178 \mathrm{D}$ \\
\hline Eyyubi & $8021 \mathrm{de}$ & $7820 \mathrm{e}$ & $7920 \mathrm{~B}$ \\
\hline Firat 93 & $7469 \mathrm{e}$ & $6749 \mathrm{f}$ & $7109 \mathrm{C}$ \\
\hline Güneyyıld1z1 & $8528 \mathrm{~cd}$ & $8483 \mathrm{e}$ & $8005 \mathrm{~B}$ \\
\hline Sarıçanak & $9292 \mathrm{ab}$ & $8484 \mathrm{~cd}$ & $9034 \mathrm{~A}$ \\
\hline Şahinbey & $9585 \mathrm{a}$ & $8862 \mathrm{~b}$ & $8644 \mathrm{~A}$ \\
\hline Zühre & $8427 \mathrm{~cd}$ & $7430 \mathrm{~B}$ & \\
\hline Total & $7950 \mathrm{~A}$ & 4.43 \\
\hline CV(\%) & \multicolumn{3}{|}{} \\
\hline LSD $(0.05)$ & $\begin{array}{l}\text { Method of planting :21.01301* } \\
\text { Varietes :40.32398** } \\
\text { Varietes x method of planting:57.02671* }\end{array}$ \\
\hline
\end{tabular}

$* *=$ means significiantly level of $1 \%, *=$ means significiantly level of $5 \%, \mathbf{N S}=$ not significiantly

study. On the other hand, the grain yield already was high in all region during 2010-2011 season than other season. I think cause of gap between this different two study is depend on different productive season. According to Jones and Singh (2000); Olesen et al (2000) and Wheeler et al (2000), factors like weather conditions and soils are important causes for crop yield variability. It is concluded that method planting on saddle gave good growth and seed production to compare with conventional planting system, because it have been used little seeds than conventional planting. So, we recommended method of planting on saddle for successfully grown wheat on permanent bed after cotton harvest. On the other hand, Especially, If the seed is not enough, the time is late and the fields is muddy for sowing, then, It can be implement successfuly method of saddle sowing. 


\section{REFERENCES}

Aydın, N., Tugay, E., Sakin, M.A. and S. Gökmen (1999). The determination of Yield and quality characteristics of durum wheat varieties in Kazova slap conditions The Symposium on Problems and Solutions of Grain Agriculture in Central Anatolia page: 621-625, 8-11 June 1999, Konya, Turkey

Atl1, A., Koçak, N. and M. Aktan(1999). The environmental conditions of country is assessment in terms of conformity to grow high-quality durum wheat. The Symposium on Problems and Solutions of Grain Agriculture in Central Anatolia, page: 345-351, 8-11 June 1999, Konya, Turkey

Hussain S, Sajjad A, Hussain MI.and M. Saleem(2001). Growth and yield response of three wheat varieties to different seeding densities. Int. J. Agric. Biol. pp. 1560-8530.

Jones, J.M. and M.Singh(2000). Time trends in crop yields in longterm trials. Exp. Agric. 36, 165-179.

Kabakçi Y (1999). The effects of different planting methods and seed rate onto grain yield. General Directorate of Agricultural Researches, Min of Agriculture. Result report. Project code no. TAGEM/IY/97/01/03/009. From: http//www.Tagem.gov.tr.

Kendal, E, Tekdal S., Aktaş H., Altıkat A.,Karaman M. and İ.Baran (2011). Determination of foreign spring durum wheat varietes suitable to Diyarbakır ekolojical conditions, Faculty of Agriculture in Uludag University, Agriculture Congress of Field Crops in Turkey VIII th., Volume 1 - page: 242-245, 12-25/September 2011 Bursa,Turkey

Kiliç, H. (2005). The method of ridge sowing in GAP, GATAEM, 2007/2, Diyarbakir

Kiliç, H. and S. Gursoy (2010). Effect of seeding rate on yield and yield components of durum wheat cultivars in cotton-wheat cropping system, Scientific Research and Essays, Vol. 5(15), pp. 2078-2084, 4 August, 2010.

Koç, S. and İ. Dursun (2007). Comparison of tillage methods aimed at protecting soil and water.2th. Workshop on Conservation Tillage and Planting, 13 June, 2007. ISBN 975-483-744-5. S:40-54. Bornova-İzmir, Turkey

Khokhar MS, Sheikh MS, Siddique M and MS Nazir (1985). Effect of different seeding densities and nitrogen levels on the yields of two whet genotypes. Pakistan J. Agric., 6: 150-152.

Larson E and R .Watson (2010). Planting Methods and Seeding Rates for Small Grain Crops. Publication 2401 Extension Service of Mississippi State University, cooperating with U.S.Department of Agriculture.

From http://msucares.com/pubs/publications/p2401.pdf

Mollah MIU, Bhuiya MSU and MH Kabir (2009). Bed Planting - A New Crop Establishment Method for Wheat in Rice-Wheat Cropping System, J. Agric. Rural Dev. 7(1-2): 23-31.

Olesen, J.E., Bo“cher, P.K. and T. Jensen(2000). Comparison of scales of climate and soil data for aggregating simulated yields of winter wheat in Denmark. Agric. Ecosyst. Environ. 82, 213-228. 
SAS Institute Inc. (1990), "SAS Language Reference, Version 6, First Edition," Cary, NC: SAS Institute Inc.

Rafique SM., Rashid M., Akram MM, Ahmad J., Hussain R.and A.Razzaq(2010). Optimum seed rate of wheat in available soil moisture under rainfed conditions. J. Agric. Res. 47(2).

Sade, B., Topal, A. and S.Soylu (1999). Determination of durum wheat varieties grown under irrigated conditions in Konya. The Symposium on Problems and Solutions of Grain Agriculture in Central Anatolia, page: 91-96, 8-11 June 1999, Konya, Turkey

Sayre KD and Moreno ROH (1997). Application Of Raised Bed Planting System to Wheat. Wheat Program Special Report No. 31. CIMMYT. Mexico. D.F.

Wheeler, T.R., Craufurd, P.Q., Ellis, R.H., Porter, J.R. and P.V.Vara Prasad (2000). Temperature variability and the yield of annual crops. Agric. Ecosyst. Environ. 82, 159-167. 